\title{
GOVERNMENTAL RESPONSIBILITIES IN THE FIELD OF LOCAL BURDENS ON RAILROAD TRANSPORTATION FACILITIES
}

\author{
David I. Mackie*
}

The recent business recession has brought into sharp focus the precarious financial situation of many of the country's leading railroads. Congressional hearings instigated by Senator Smathers in 1957 gave wide publicity to the progressive inability of rail carriers to produce sufficient revenue to meet their continually mounting expenses. The report ${ }^{1}$ which followed those hearings particularly emphasized that a principal cause of this deteriorating situation was the astronomical deficits incurred, particularly by eastern railroads, in operating passenger services. ${ }^{2}$ Heavy losses from rendering commuter and other local passenger service were specifically stated to have faced "several large carriers in the East . . . with the imminent threat of bankruptcy."3 Hearings conducted at about the same time by the Interstate Commerce Commission on its own motion led to the submission of a proposed report which reached similar conclusions and ended with the prediction that the situation was so hopeless that most rail passenger service would be discontinued by $1970 .{ }^{4}$ In the course of that report, the examiner referred to a study indicating that 18.5 per cent of the so-called passenger deficit ${ }^{5}$ of Class I carriers throughout the country was attributable to commuter operations. ${ }^{6}$ In the case of individual railroads serving large urban centers, the percentage is obviously much higher.

The threat which the situation poses to the continuance of commuter services has become a source of alarm in metropolitan centers, both to their patrons and to the communities in which they operate. The plight of the railroads providing such services in metropolitan areas is currently headline news, almost daily, in the public press. Recommendations for special city commissions, state commission, bi- and tristate commissions, all attest the concern of the public and its officials and emphasize

*A.B. 1926, Williams College; LL.B. 1929, Harvard University. Member of the New York bar; Chairman, Eastern Railroad Presidents Conference.

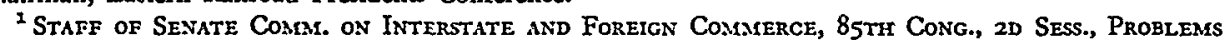
op the Railroads, Report of the Subcommittee on Surface Transportation (Comm. Print 2958 ).

${ }^{3} I d$. at 3 .

${ }^{3} I d$. at 4. See also the statements of Messrs. Alpert, Perlman, and Symes in Hearings Before the Subcommitiee on Surface Transportation of the Senate Committee on Interstate and Foreign Commerce on Problems of the Railroads, 85th Cong., 2d Sess., pt. I, at 4r I, 227, 74, 144 (1958).

- Railroad Passenger Train Deficit, No. 31954, Examiner's Proposed Report, ICC, Sept. 18, 1958.

"The term "passenger deficit" refers to the amount by which the revenues from passenger-service operations fall short of covering operating expenses, taxes, and net rents assigned or apportioned to this service. Id, at 2-3.

Id. at 18 . 
their conviction that "something must be done." As stated by Governor Rockefeller, of New York: "We have passed the time for study. We have reached the time for action." "The seriousness of the problem has been proclaimed not only at the local governmental level, but also with compelling urgency at the federal level. The senate report above referred to states categorically that the commuter-service problem is $^{0}$

a matter of deep concern to the Federal Government because of the impact that losing commuter service can have on the ability of an interstate rail carrier to render its interstate service. . . Because of the burden that these losing intrastate services are imposing on interstate commerce, the subcommittee feels that the Federal Government can no longer stand aside to the extent it has in the past.

Despite these expressions of concern, which might suggest possibilities of federal encroachment on private management or on the powers of local government, nearly all the recommendations which have been made presuppose that rail carriers must be kept operating under private management and, more importantly, that primary responsibility for action lies with the local communities affected. The senate report explicitly states that it is "desirable to leave to the local government agencies involved the job of seeking specifically tailored solutions to their particular problem."10 That approach is regarded as eminently sound. It is, accordingly, the purpose of this paper to review two of the underlying causes of the problem, to examine one of them in detail, and to indicate the scope of its solution at the local level, together with the existence, and consequently necessary exercise, of federal power if local responsibility continues to be ignored.

At the outset, it is important to underscore the fact that transportation has always been a primary concern of government at every level. The reasons for that concern are obvious. Waterways and railroads were the means by which vast areas of this country were opened up, developed, and knit together into a nation. Today, those agencies of transport, together with the motor carriers and the air lines, are the means whereby raw materials and manufactured goods are moved from one part of our highly industrialized nation to another; railroads, airlines, buses, and private automobiles are the means by which people are transported about the country. Without this all-embracing, flexible transportation system, industry and agriculture would wither and die, national defense would become an empty phrase, and the mobility of personal life to which men and communities have become accustomed, and upon which they rely, would become impossible.

With the growth of population and expansion of our economy, government responsibility for transportation has necessarily both widened and deepened. In-

${ }^{7}$ E.g., Baltimore, where the Greater Baltimore Committee recommended that a mctropolitan transit authority be established to exercise effective supervision over all forms of transportation in the metropolitan. area. Baltimore Sun, Jan. 22, 1959, p. 32, col. 4 .

${ }^{8}$ Speech of Governor Nelson Rockefeller delivered before Republican Victory Dinner in Hotel SheratonAstor, New York City, Jan. 28, r959.

'Staff of Senate Comm. on Interstate and Foreign Commerce, op. cit. supro note 1 , at 4.

${ }^{10} \mathrm{Id}$. at 5 . 
creasingly, every section of the economy depends on some form of transportation to move not only freight, but passenger traffic. Specialization in industry has brought about progressively greater division of labor, which has intensified the need both for mobility and for coordination of the means which make that mobility possible. The continuing dispersal of population from urban and industrial centers is among the significant economic facts of our time. In consequence of this development, much of which has occurred since World War II and accompanied the new housing programs of the last decade, enormous numbers of men, women, and children have to be moved every weekday to and from industrial plants, offices, and schools. Mass transportation needs for such commuter travel has, therefore, become one of the most pressing responsibilities of state and local governments. Moreover, the threat which the use of alternate methods-notably the private automobile-poses to metropolitan centers in terms of parking, maintenance of streets and bridges, and traffic control is a source of increasing concern to city officials. In a recent speech made before a meeting of the mayors of principal American cities, specially assembled to "consider the commuter problem, Mayor Wagner of New York stated: ${ }^{11}$

If we allow mass transportation to deteriorate-indeed, if we don't help improve it-we place in possible jeopardy the economy of our metropolitan regions.... Mass commuter transit ... constitutes an essential service, indeed a matter of survival, for metropolitan areas.

Notwithstanding this apparently growing concern at the local-level for the future of passenger train service, doubt has been expressed as to what, if anything, state and local governments may be able to accomplish. A concurring opinion in the report of the New York Public Service Commission recently stated: ${ }^{12}$

The problem of passenger deficits, even with respect to the New York railroads, is basically a national and not a state problem.

Traditionally, no doubt, the welfare of an over-all transportation system has been a responsibility of the federal government. Long ago, commerce ceased to be local and became national, with the result that Congress has, from time to time, gone to great lengths to promote particular forms of transportation. In the nineteenth century, rivers and canals, later railroads, received substantial government aid in the form, respectively, of appropriations and land grants. By the twentieth century, such benefits ceased to be conferred upon the railroads, but highways, waterways, and airways received, and are still receiving, enormous subsidies. Promotion of this kind has been accompanied by government regulation for the benefit both of the carriers and of the public. The public interest in safety, adequacy of service, and reasonable rates resulted in the enactment of such regulatory acts as the Interstate Commerce

\footnotetext{
${ }^{11}$ Statement by Mayor Robert F. Wagner on commuter transportation' before a "conference of a group of mayors of major cities and representatives of eastern and western railroads, Chicago, Ill., Jan. I3, 1959, N. Y. Times, Jan. I4, I959, p. I, col. 1 .

1 i Public Service Comm'n, Report of Investigation of 'the Financial Condition of the Railroads Operating in the State of New York 61 (I959).
} 
Act in $188 \%,{ }^{13}$ the Motor Carrier Act in $1935,{ }^{14}$ the Civil Aeronautics Act in $1938,{ }^{15}$ and the Water Carrier Act in $19400^{16}$ Mindful of the competitive conditions under which transportation is conducted, Congress enacted in 1940 a declaration of policy to the effect that rail, highway, and waterway transportation subject to the Interstate Commerce Act, as amended, should be so regulated as to recognize and preserve the inherent advantages of each mode of transportation within the framework of fair and impartial regulation and to foster sound economic conditions. ${ }^{17}$

The national importance of transportation has also meant that the federal courts as well as Congress have been prompt not only to promote it, but to remove impediments placed in its path by state and local governments. As early as 1824 , the Supreme Court, in Gibbons v. Ogden, turned to the commerce clause of the Constitution to strike down restrictions imposed by a state on interstate commerce. ${ }^{18}$ In the Minnesota Rate Cases, in $19 x_{3}$, the Supreme Court made it plain that state control over intrastate rates was to be subordinated to federal regulation of interstate rates whenever the two conflict. ${ }^{19}$ And in $19 \mathrm{r}_{4}$, in the Shreveport Cases, the Court held Congress could authorize the ICC to remove discrimination against interstate commerce by prescribing a change in intrastate rates which were so low as to cause discrimination. ${ }^{20}$

Unquestionably, therefore, the federal government has not only the power, but an ultimate responsibility to oversee the welfare of intrastate as well as interstate transportation. That responsibility will undoubtedly be exercised if the units of local government primarily concerned do not act in time.

\section{The Patrern of Discrimination}

Among the causes of current railroad difficulties brought out in the $195^{8}$ congressional hearings were those resulting from the vast subsidies which the railroads' competitors receive from the federal and state as well as local governments. Some 28,000 miles of navigable inland waterways, dams, locks, and channels, as well as seacoast and harbor improvements, are provided without cost to commercial users. ${ }^{21}$ In fiscal 1959 alone, federal aid for highway construction and improvement was authorized in the amount of nearly $\$ 3,500,000,000$ for the benefit of private automobile and commercial users. ${ }^{22}$ Extensive payments and subsidies are likewise made to airlines and airway systems and for the construction and maintenance of airports and navigation facilities. According to announced plans, a total of $\$ 2,800,000,000$ is to

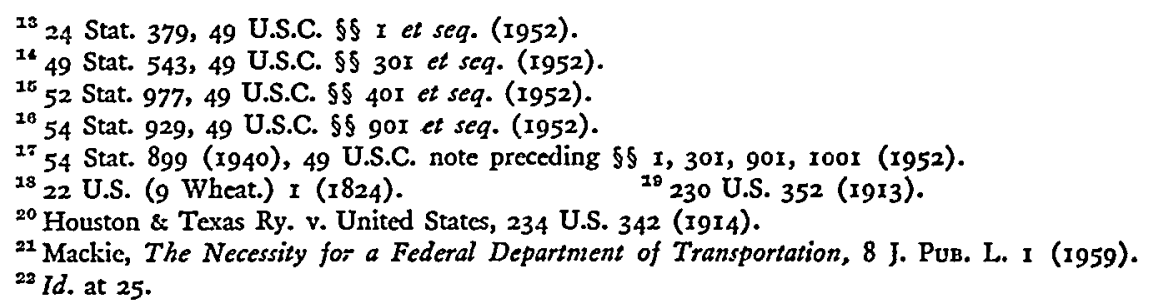


be spent for airways facilities and services in the period $1959-63 .{ }^{23}$ The federal government has already contributed over $\$ 1,000,000,000$ for the construction of civil airports. ${ }^{24} \mathrm{~A}$ bill has been enacted by the Eighty-sixth Congress to extend for a further four-year period the federal airport-grant program that expired on June 30 , 1959. Authorized federal aid for this period totaled $\$ 297,000,000.25$

No subsidies are available to the railroads. The result of these activities of the federal government, therefore, has been to effect substantial reductions in the operating costs of water, air, and motor carriers, which are consequently in a position to establish rates and fares which divert traffic from the rails. These competitive inequalities must be corrected, or continued financial deterioration of the railroads, and even bankruptcies, may be anticipated. While this situation is one of which Congress has become aware, much corrective action is still required. Current, carefully circumscribed proposals to create a Federal Department of Transportation, in which the Government's promotional activities with respect to all forms of transportation would be centered and coordinated, could provide much needed relief in this area. ${ }^{28} \mathrm{Sim}-$ ilarly, the study presently being conducted by the Secretary of Commerce, as directed by the President ${ }^{27}$ likewise holds hope of indicated solutions.

These difficulties at the national level, however, are matched by like difficulties arising out of competitive inequalities fostered at the state and municipal levels. Here, again, substantial subsidies are provided the railroads' competitors, but at these levels, the problem of competitive inequality is compounded by the heavy and discriminatory taxes imposed on rail carriers. Direct aid is provided to the railroads' competitors-water, motor, and air carriers-in the form of port, highway, and airport construction, paid for out of general public funds. Indirect aid, in the form of tax relief and tax exemption, has relieved those competitors from substantial operating costs, with the result that they are enabled to charge artificially low rates, which, in turn, diverts traffic from the rails. No such direct or indirect aid is afforded the railroads. On the contrary, they are not only mercilessly taxed by almost countless local authorities, but tax-free, publicly-built express highways and tunnels encourage the railroads' patrons to resort increasingly to the private automobile for transportation. The staggeringly high costs of doing business under such conditions of competitive inequality and of continuing attrition of traffic have reached the point at which progressive curtailments and abandonments of passenger services are inevitable unless remedial action is taken. Absent such action, these discontinuances will have their greatest impact on the one type of service most urgently needed by local communities-high-speed, efficient rail commutation service.

${ }^{23} I d$. at 26.

26 ld. at 27 .

${ }^{25} 73$ Stat. 155 (1959).

${ }^{20}$ Mackie, stupra note $2 x$, at 38 .

${ }^{27}$ Budget Message of the President, in U.S. Bureau of the Budget, op. cit. supra note 25, at M-5, $\mathrm{M}-46$. 
It must not be supposed that the provision of operating facilities and tax exemptions to the railroads' competitors, and the exaction of exorbitant taxes on rail plants and facilities are the only burdens which are imposed upon railroads at the local level. Curtailment of inträstate services and the authorization of fare increases are within the jurisdiction of state commissions which have frequently been reluctant to afford even the most imperatively needed relief. ${ }^{28}$ The serious implications of the failure of some state commissions to grant needed relief in these areas led in 1958 to the invocation of federal power through addition of a new section 13 a to the Interstate Commerce Act. ${ }^{29}$. No relief has yet been afforded from either the local burdens of competitive inequalities or of tax assessments. "It is in these areas that relief is most urgently needed. Indeed, both the report of the senate committee ${ }^{30}$ and the examiner's proposed report ${ }^{31}$ emphasized the impact of those burdens upon rail carriers.

Each of these two types of local burdens-competitive inequalities and tax assessments-that fall with staggering incidence on the railroads is of tremendous significance. The tax burden is particularly heavy in certain jurisdictions. The cost of local government has risen greatly in the last twenty-five years not only because of increasing wages and salaries, but because of citizens' demands that government continually expand its services and functions. Taxes have been increased and multiplied, and they have fallen most heavily on companies, like the railroads, which have enormous fixed plants sprawled across the face of the countryside and are subject to almost countless local taxing authorities. As public utilities, having relatively fixed incomes and being unable frèely to raise their rates and charges to meet increasing taxes and other costs, their margin of profit can quickly become a margin of deficit. Figures in the recent report of the New York Public Service Commission ${ }^{32}$ bring this point into formidable relief. The forty-seven railroads operating in New York State pay real estate taxes in the state to II42 cities, towns, and villages ${ }^{83}$ in fifty-seven counties, ${ }^{34}$ exclusive of the City of New York, and, in addition, pay taxes based upon real estate to some 5000 school and special districts throughout the state. ${ }^{35}$ The New York Central Railroad alone is subject to tax by more than 2700 individual taxing agencies in the state. ${ }^{36}$ The burden of these taxes is demonstrated by the fact that while "between I955 and 1957 the combined net income of the State's railroads dropped from $\$ 165$ million to $\$ 76$ million, or $53.9 \%$; in the same period their real property tax bill increased from $\$ 38.9$ million to $\$ 42.5$ million, or $9.3 \%$ :" The total

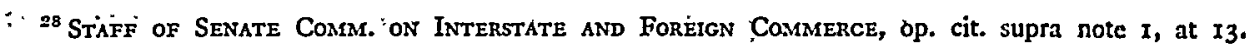
${ }^{29} 72$ Stat. 571, 49 U.S.C.A.. \& 13x. (Supp. 1958). "See Great Northern Ry. Co.-Discontinuance of Service, No. 20348, ICC, Feb. 6, 1959; New Jersey v. Ưnited States, I68 F. Supp. 324 (D. N.J. I958), affd, 359 U.S. 27 (I959).

${ }^{30}$ Staff of Senate Comm. on Interstate and Foreign Commerce, op. cit. supra note $\mathrm{I}$.

${ }^{81}$ Railroad Passenger Train Deficit, No. 31954, Examiner's Proposed Report, ICC, Sept. 18, x958.

${ }^{33}$ Public Service Comm, op. cit. supra note 12, at 10, app. 12. . .

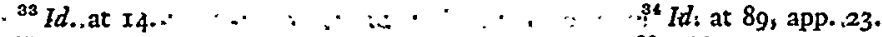

${ }^{35} \mathrm{Id}$. at I4.

so Ibid. 
taxes paid by these railroads in 1957 to the State of New York and its varrous taxing agencies amounted to $\$ 45,100,000 .^{37}$

The plight of the railroads which operate in the State of New Jersey, particularly those which provide extensive passenger services, has become a subject of almost daily comment in eastern newspapers. The acuteness of the situation arises from the fact that New Jersey imposes on rail carriers a franchise tax and four types of property taxes. The franchise tax is a ten per cent tax on that portion of the carrier's net railway operating income which is attributable to New Jersey, which is arrived at through a formula of the ratio of total track miles in New Jersey to total system track miles; the property taxes are made up of levies upon four classes of property. ${ }^{\mathbf{3 8}}$ Each tax is, by itself, a standard type in common use. However, when combined, these five taxes have, over the five-year period from 1953 to i 957 , cost the eleven Class I railroads operating in New Jersey an average of $\$ 2.65$ for every dollar of net income earned in that state; and in the year 1957, the latest year for which figures are available, the cost was $\$ 3.5^{8.39}$ Figures based upon net operating income for particular railroads reveal, for example, that in 1958 , the Pennsylvania Railroad paid out $\$ 5,829,976$ in taxes, although earning only $\$ 702,180$ of net operating income allocated to New Jersey on the basis of that state's own formula; and the New York Central Railroad paid out $\$ 1,562,205$ in taxes, although earning only $\$ 78,252$ of net operating income so allocated to New Jersey. ${ }^{40}$

If the combined taxes levied on a carrier by one state exceed the earnings properly attributable thereto, the carrier must draw upon and deplete its earnings elsewhere in order to pay the tax bill of a single state. Quite obviously, if every state in which an interstate railroad operates exacted taxes on a similar basis, insolvency could easily result. If, for example, the New Jersey basis were extended into all states in which the Pennsylvania Railroad operates, the total system taxes would be $\$ 97,416,000$, as compared with their present level of $\$ 31,442,000 .^{41}$

New Jersey has the distinction of leading all the States in the amount of taxes per mile of road which it levies against railroads. Its toll in 1956 was \$ro,244 per mile, which was more than 5 times the national average. The railroads have a long-standing grievance against the New Jersey taxing authorities for assessing their property at Ioo per cent of value and recognizing a lower basis for other taxpayers. The State Supreme Court has found that the railroads have a just cause of complaint but various administrative pretexts have been employed to perpetuate the injustice. ${ }^{42}$

${ }^{37}$ Id. at $\mathrm{r} 5$.

${ }^{88}$ N.J. Stat. ANN. $\$ \$ 54: 29 A, 54: 29 A-\times 4$ (Supp. 1958) (franchise tax); id. $\$ 54: 29 A-r 7$ (Class I, II, and III property tax applicable to main stem, other real property used for railroad purposes, and tangible personal property, respectively); id. $\$ 54: 29 \mathrm{~A}-4$ (all property not used for railroad purposes assessed and taxed in the same way as other local property).

${ }^{30}$ ICC ANn. Rep. (1954-58); N.J. Dep'T of Treasury Rep. (I954-58).

"Computations based upon those used in Tax Statement, Assessment after Review by the Director, Division of Taxation, Department of the Treasury, State of New Jersey.

"Calculation supplied by the Director of 'Taxation of the Pennsylvania Railroad Company.

${ }^{2}$ Railroad Passenger Train Deficit, No. 3 r954, Examiner's Proposéd Report; İç, Sepț." 18, 1958, p. 46, citing Delaware, L. \& W. R.R. v. Neeld, 23 N.J. 56r, 130 A.2d 6 (r957): 
It may also be noted that the State of New York has the similarly dubious distinction of taxing the railroads operating within its boundaries at three times the national average. $^{43}$

A few years ago, the Pennsylvania Railroad was required by the New Jersey Public Utility Commission to install moving stairs in its passenger stations at Trenton and New Brunswick, costing respectively $\$ 186,000$ and $\$ 90,000$. The taxing authorities thereafter increased the assessments on the station properties which included these facilities and thereby raised the annual taxes on those facilities in the amounts $\$ 3,926$ at Trenton and $\$ 1,248$ at New Brunswick.44

The New Jersey tax situation, though presently unique, is emphasized because that situation is one that appears to be gradually and relentlessly approaching in other jurisdictions. For example, Mr. A. E. Perlman, President of the New York Central System, testified before the Subcommittee on Surface Transportation at the $195^{8}$ hearings that from 1954 to I955, the New York Central's taxes on the passenger bridge over the Harlem River, in New York City, were multiplied 700 per cent, from $\$ 70,000$ to $\$ 490,000$ a year, and the franchise tax for the right to use the underground tunnel into Grand Central Terminal jumped from $\$ x, 050,000$ a year to $\$ 2,500,000$ a year. ${ }^{45}$

At the same hearings, Mr. John Budd, President of the Great Northern Railroad, pointed out that in School District No. 7 of Lincoln County, Montana, the railroad pays $91.3^{8}$ per cent of all school taxes levied in the entire district, even though the railroad's $26_{5}$ acres, consisting only of main line trackage and a single siding, constitute but 0.335 per cent of the 79,200 acres in the district. ${ }^{40}$

None of these taxes, taken singly, might be found to burden commerce, however much they may burden a particular railroad; but the steadily mounting total tax burden is not only impairing the financial stability of rail carriers, but is making it impossible for them properly to perform their interstate business. Thus, the problem is not merely one of preventing multiplicity of taxes, but of reducing the total tax burden in a single state and, more importantly, of lightening the combined, cumulative burden of taxes in all states. The existing situation obviously presents an alarming threat to the solvency of rail carriers and, in addition, to the public interest in the continuance of sound and efficient rail transportation.

State and local tax rates on railroads are not only staggeringly large in the aggregate; many of them are also discriminatory. In New Jersey, for example, railroads pay a franchise tax at a higher rate than general business corporations. ${ }^{47}$ Other states also impose taxes at rates which are unduly discriminatory to railroads, as contrasted with other types of businesses: for example, the Ohio excise tax of four per cent on all intrastate gross earnings, and the West Virginia transportation tax of

${ }^{8}$ ICC, Bureat of Transport Economics and Statistics, Seventieth Ann. Rep. on Transport Statistics in the United States for the Year Ended Dec. 31, 1956, at 69, table 107 (1957).

« Railroad Passenger Train Deficit, No. 31954 , Examiner's Proposed Report, ICC, Sept. 18, 1958, p. $4^{6}$

15 Hearings, supra note 3 , pt. $\mathrm{X}$, at 229.

${ }^{40} I d$. at 455.

${ }^{17}$ N.J. Stat. AN. $\$ \$$ 54:29A-13, -14, -15; 54:10A-5 (Supp. 1958). 
four per cent on taxable net income allocated to the state together with a surtax which amounts to thirty per cent of the normal tax..$^{48}$

Local valuations as well as local tax rates are also frequently discriminatory. In several states, notably in New Jersey and New York, the valuation placed upon railroad properties is higher than that upon other types of business. In New York, for example, the New York Central Railroad discontinued its car repair shops which were carried on the tax rolls of West Albany at $\$ 1,500,000$. The railroad was unable to sell the property for more than $\$ 500,000$, and when the new owner took possession, the assessment was lowered to $\$ 300,000.99$

Discrimination by local communities against rail carriers is not confined to taxation. Every year, local communities are constructing facilities for competitors and freeing them of taxes. Thus, for example, Boston's Logan Airport was built with funds provided by the federal, state, and city governments at a cost of more than $\$ 74,000,000$. Those payments were financed from funds to which the general taxpayer, including the New Haven, the Boston \& Albany, and the Boston \& Maine Railroads, of course, contributed. In addition, the 2000 acres (more than three square miles) occupied by the airport for the benefit of air travelers were freed of taxes, which thus had to be levied upon other properties, including those of the railroads. By contrast, the South Station in Boston, built and maintained by private railroad capital, occupies a mere thirty-one acres but is required annually to pay out of the revenues of the New Haven and Boston \& Albany Railroads taxes in excess of $\$ 1,000,000 .^{50}$ This means that, since the expenses of those railroads are reflected in their fares and charges, rail passengers are helping to subsidize air passengers and, in addition, are paying disproportionate shares of their fractional contributions to city taxes. Moreover, to the extent that rail passenger services are operated at a deficit, in fact a substantial part of the air passenger subsidy is paid for out of revenues derived from freight shipments.

Comparable situations exist in other cities. For example, the City of Toledo, Ohio, completed its Express Airport in 1955 at a cost of \$3,865,228 out of city funds to which railroads serving the city contributed along with other taxpayers. Owned and operated by the city, this airport pays no taxes and is, in fact, operated at a deficit. These operations, including the deficit, are financed out of city funds to which, again, the railroads contribute. By contrast, five years previously, the local chamber of commerce filed a complaint against the New York Central Railroad, alleging discrimination in failing to build a new station, and thereby forced that railroad to provide a new station, out of railroad funds, at a cost of $\$ 4,856,745$. The property is taxed at over $\$ 40,000$ a year. ${ }^{51}$

\footnotetext{
${ }^{48}$ Ohio Rev. Code ANv. $\$ \$ 5727.01-5727.62$; (Page 1954); W. VA. Code ANs. $\$ 5958(17)$ [5], 958 (17a) [52] (Cum. Supp. 1958).

${ }^{\circ}$ Albany Times Union, May 24, 1958 , p. 4, cols. I and 2.

${ }^{60}$ Testimony of Hollis H. Coyle, in Railroad Passenger Train Deficit, No. 3r954, ICC, March 20, 1958, item $\mathrm{II}$, at 2,3 .

${ }_{51}$ Testimony of J. S. Gallagher, Jr., id., April 7, 1958, item 10, at 5, 6; April 8, 1958, item II, at II.
} 
It is clear from these examples that these high local taxes which the railroads are forced to pay are frequently the result of assessments upon passenger facilities, which nearly everywhere are operated at a loss. This is particularly true of facilities that are used for the suburban commutation services incurring enormous deficits. Thus, the New York Central, New Haven, and Pennsylvania Railroads paid the City of New York $\$ 9,700,000$ in real estate and franchise taxes on Grand Central Terminal and Pennsylvania Station, together with their supporting coach yards. ${ }^{52}$ Annual taxes on the station facilities and the first five and one-half miles of its track out of Grand Central Station amount to more than seventeen per cent of total franchise and property taxes assessed against the entire ro,70o-mile New York Central System. ${ }^{\text {b3 }}$ By contrast, the Port of New York Authority, in lieu of taxes, pays the City of New York only $\$ 450,000$ a year rental for LaGuardia and Idlewild International Airports. On the basis of local assessment rolls, these two facilities would, if privately operated, be required to pay taxes to the City of New York approximating $\$ 7,268,000$ annually. ${ }^{54}$

Railroads are thus not only overtaxed and taxed disproportionately, but they are discriminated against in favor of competitors. In addition, neither those competitors nor their patrons pay their fair share of user charges for facilities provided by state and municipal authorities, with the result that those charges are borne by the general public, including, of course, the railroads. The user subsidy provided to patrons of the airports in the New York City area is particularly striking. Helicopter service from Idlewild International Airport to the Port Authority Heliport is available at $\$ 7.00$ plus tax. In 1957 , the federal government paid the airline furnishing that service a subsidy equivalent to $\$ 3.08$ for each $\$ \mathrm{x}$ of passenger revenue earned. That amounted to $\$ 21.56$ on each $\$ 7.00$ ticket. ${ }^{55}$ Again, Westchester County's Airport is maintained in part by the county for the use of two small airlines and for the executive planes of fifty-six large private corporations. Yet, the residents of the county willingly contribute thereto but oppose any contributions to the surburban service of the New York Central and New Haven Railroads, which carry tens of thousands of persons to and from New York every day. ${ }^{56}$

The inadequacy of user charges at the local level is especially conspicuous in the case of highways. The trucking industry moves enormous highway freighters over state-built and state-maintained public roads which are financed in large measure both out of general tax funds, to which the railroads contribute, and out of vehicle and gasoline taxes, to which the private motorist makes substantial contributions. Thus, the trucks have not one, but two completely artificial competitive advantages over the railroads: on the one hand, the rights of way on which they operate are

${ }^{52} I d$. at 38 .

${ }^{53}$ Figures supplied by J. S. Gallagher, J'.,', Director of Passenger Research, Forecasting and Controls, New York Central System.

Es Testimony of J. S. Gallagher, Jr., in Railroad Passenger Train Deficit, No. 31954, ICC, April 8, I958, item II," at 36 .

${ }^{55}$ New York Airways, INc., 1957 ANw. Rep. (1958).

' ${ }^{\circ}$ Speech of A. E. Perlman, before Westehéster County Association, Nov. 25, 1958. 
provided and maintained largely out of funds supplied by the general taxpayer and other highway users rather than out of user charges fairly assessed against them for their share of highway use; on the other hand, those rights of way are entirely free of taxes. By contrast, the railroads have built and currently maintain their rights of way out of their own, rather than out of public, funds; and they pay full taxes upon those facilities. In consequence of the situation, trucking companies have lower operating costs than railroads and can reduce their charges for moving numerous types of traffic below the level of railroad charges. In this way, not only is traffic diverted from the railroads, to their continuing financial loss, but the general taxpayers foot the bill for the difference between what the trucks do charge and what they would have to charge if user charges and taxes on their highway facilities were assessed against them.

\section{II}

\section{REMEDIAL ACTION}

Although there are indications that increased state gasoline and weight-distance taxes may bring about more fairly apportioned user charges and thus help to relieve the railroads of one of the presently existing inequalities of the rail-truck competitive situation, it is unrealistic to suppose that either the states or their municipalities would consider direct payments for the construction, improvement, or maintenance of rail facilities to match those made for air, highway and water facilities. It is also unrealistic to suppose that highway, airport, and water facilities could be subjected to state and local property taxes in order to bring about fair conditions in the tax area. Nevertheless, equality in that area can logically and realistically be achieved by freeing from ad valorem and in lieu taxes all railroad rights of way and terminal facilities. The tax exemption which has always been, and is currently, afforded highways, waterways, and airways reflects a policy that the "highways of commerce" should be free of taxes; and, surely, the railroads are as entitled to the benefit of that concept as are their competitors. This proposal, it must be emphasized, is based upon entirely different considerations from those involved in the exaction of fair user charges for facilities provided air, water, and highway users at public expense. User charges are designed and assessed in order to pay for construction, maintenance, and administrative costs of publicly-provided transportation facilities. Ad valorem and in lieu taxes, on the other hand, are assessed to pay for the general costs of government. If such taxes are to continue to be employed to support air and highway transport, they should be used for the benefit of all forms of transportation. It is as unfair and as illogical to require railroads to continue to help subsidize their competitors as to require that railroads be subsidized by their competitors. Equality can be attained only by treating alike all forms of transportation.

Proposals looking toward less comprehensive relief in the field of taxation have recently been advanced. Thus, a spokesman for the Chicago railroads recently stated it to be their position that taxes on railroad property should be "non-discriminatory 
and bear a realistic relationship to earning power." ${ }^{57}$ The New York railroads, on the other hand, are currently supporting exemption from taxation of all real property used in connection with railroad passenger service. ${ }^{58}$ Although both of these objectives are sound, and while their accomplishment would doubtless to some degree alleviate the current financial problem, it is submitted that correction of the evil requires more drastic as well as more comprehensive treatment. If our national policy is to continue to exempt from ad valorem and in lieu taxation the "highways of commerce" other than those used by railroads, as it assuredly is, then equality of competitive opportunity can only be achieved by exemption from ad valorem and in lieu taxation of rail "highways of commerce." The principle should be applied to all rail transportation facilities-be they passenger or freight. No distinction as to use applies in the case of highway, waterway, or air facilities, and none should apply to rail facilities.

Suggestions have been made that the passenger deficit problem should be resolved by government subsidies at the federal level. Certainly subsidies are nothing new in American government. Direct subsidies to mining and agriculture are accepted features of every national budget, as are grants-in-aid made every year to the several states. Indirect subsidies through tariffs are almost as old as the Republic. More recent forms of indirect subsidies include income tax benefits and fast depreciation write-offs for certain types of industry. It is conceivable that Congress might decide to subsidize the railroads as it has the feeder airlines. Federal subsidies, however, especially in the public utility field, are unpalatable to many people who fear therefrom progressive governmental interference in private enterprise. It is, therefore, more realistic, and probably more sensible, to suggest that local communities, which have a primary responsibility for local conditions, undertake to equalize at least the local competitive conditions under which all forms of transportation operate. Because of the manner in which railroad transportation has developed-that is, initially financed out of private capital-it seems unlikely that local communities would favor outright payments to railroads designed to match those pard out for building airports and highways. Tax exemption for the railroads, however, is a different matter, because it would merely extend tax exemptions now accorded the railroads' competitors in a manner to bring about tax equality. Equality of taxation is not subsidy.

It is essential that the problem of local burdens on rail carriers be viewed from the standpoint of public need for continuing adequate transportation service rather than from the standpoint of classical tax concepts. Typical of the attitude of local taxing authorities is the position that railroads must be taxed like other industries. Characteristically, these authorities argue that any industry that loses money is no less subject to property taxes and that the losses or costs of doing business must fall upon the owners of that business. It is also argued that property which is totally

${ }^{8 \pi}$ C. M. Roddewig, President, Association of Western Railways, Press Release, Jan. 13, 1959.

see S. 1030, Ass. 1378, N.Y. (1959). 
unproductive-such as a vacant building-is always subject to taxes. The answer to these arguments is that a private industry, when losing money, can raise its prices, sell its property, reduce the scope of its activities, or liquidate its business. Likewise, a vacant building, if sufficiently unproductive, will be sold or torn down. A railroad cannot sell or destroy its plant; neither can it raise its prices, abandon its services, or liquidate its business-short of bankruptcy proceedings-without the consent of state or federal regulatory bodies. These characteristics of the railroad business provide the key to the problem: railroads are utilities affected with a public interest which is so paramount that almost from the beginning they have been, and continue to be, subject to regulation by government. The concept of regulated industry carries with it numerous legal consequences which either displace or substantially modify both the law of the market place and many traditional legal concepts. Not only is it not in the public interest, but it is wholly contrary to and at variance therewith to provide railroads, faced with mounting passenger deficits attributable in substantial measure to local taxes and subsidies, with only one option: that of bankruptcy.

That some solution must be found for alleviating rail carriers' burdens resulting from high taxes and the inequalities of competitive opportunity imposed and fostered by state and local governments is obvious to any one who does not wish to see nationalized the railroads and eventually other forms of transport. The continually increasing impact of such burdens are slowly, but very surely, crippling the railroads' financial welfare and destroying their capacity to render essential services. The fact that improved service and reasonable financial well-being can result from the alleviation of local tax burdens is brought out by the record of the Long Island Rail Road Company after the enactment of legislation providing a ceiling on real property taxes levied against railroads which qualify as railroad redevelopment corporations. That legislation not only enabled the Long Island to emerge from bankruptcy and to continue operations under private management, but enabled it to embark upon a $\$ 65,000,000$ improvement and modernization program which made it possible to provide increased service and comfort for the commuting public..$^{59}$

That experience forcefully demonstrates that relief from problems created at the local level can also be solved at the local level. There are signs that other local communities are prepared to take action in certain directions. In $195^{8}$, the Massachusetts legislature voted a direct subsidy of nearly $\$ 1,000,000$ in order to keep running the Old Colony Line of the New Haven Railroad. ${ }^{60}$ In that year, also, the Pennsylvania and Reading Railroads concluded a novel arrangement with the Philadelphia Transit Company and the City of Philadelphia whereby the latter allocated $\$ 160,000$ to reimburse the two railroads for out-of-pocket costs in connection with increased commuter service meshed to the bus schedules of the P.T.C. ${ }^{\text {i1 }}$ In New Jersey, a state commission has been created to deal with and resolve the railroad passenger

\footnotetext{
${ }^{60}$ See testimony and appendices thereto of Thomas M. Goodfellow, in Railroad Passenger Train Deficit, No. 31954 , ICC, 1957 item 8.

${ }^{60}$ Mass. Acts 1958 , ch. $54 \mathrm{r}$.

${ }^{12}$ See Philadelphia Inquirer, Feb. 20, 1959, p. 4, col. 4 .
} 
problem; ${ }^{62}$ and in New York, Governor Rockefeller has recommended, ${ }^{03}$ and the legislature has enacted, legislation ${ }^{64}$ to create a State Office of Transportation to address itself to "the most critical of our present transportation problems ... that of our commuter service." Only last year, in 1958, Governor Harriman, of New York, approved a bill providing that any tax district in New York would be authorized to agree with a railroad corporation to exempt it, in whole or in part, from taxation of its real property. ${ }^{65}$ Such actions, however, are only straws in the wind and hardly come to grips with the heart of the problem.

Unless far-sighted statesmen are prepared to attack the problems firmly and vigorously at the local level, only one solution to preserve a healthy railroad industry appears possible, and that is action by the federal government. That the Government has the power to act in certain directions through the courts is unquestionable. Both the due process and the commerce clauses of the Constitution protect interstate carriers from the burden of multiple state taxes, in that they have been interpreted to limit state taxes to that portion of the interstate organism which may be properly attributable to each of the various states in which the carrier operates. ${ }^{6 B}$ Notwithstanding the apparently continuing vitality and the implications of New York C.R.R. v. Miller ${ }^{67}$ and Northwest Airlines v. Minnesota, ${ }^{88}$ the Supreme Court in 1952 , in Standard Oil Co. v. Peck, ${ }^{69}$ affirmed its position against multiple taxation of interstate operations when "the tax would have no relation to the opportunities, benefits, or protection which the taxing state gives those operations."70

If the federal courts find it impossible to act, federal legislative action to control state and local taxes is an obvious alternative. Indeed, several Supreme Court decisions have stated that a legislative solution is indicated. ${ }^{71}$ Recently, in a dissenting opinion, Mr. Justice Frankfurter insisted that the problem of conflicting and burdenensome state taxation of commerce can only be resolved by Congress after a full and thorough canvassing of the multitudinous and intricate factors which compose the problem of the taxing freedom of the states and the needed limits on such state taxing power. "Congress alone can formulate policies founded upon economic realities, perhaps to be applied to the myriad situation involved by a properly constituted and duly informed administrative agency."72

\footnotetext{
${ }^{62}$ N.J. Laws 1959 , ch. I4.

c ${ }^{\circ}$ Annual Message to the Legislature, Legrs. Doc. No. I, at A22, A25 (1959).

"N.Y. Sess. Laws x959, ch. 16. 0 N.Y. Sess. Laws 1958, ch. 970.

${ }^{8}$ Nashville, C. \& St. L. Ry. v. Browning, 3 10 U.S. 362, 365 (1940).

${ }^{\text {eq }} 202$ U.S. 584 (1906). ${ }^{682}$ U.S. 292 (1944).

${ }^{60} 342$ U.S. 382 (1952).

${ }^{70}$ Id. at $384-85$. See also Northwestern States Portland Cement Co. v. Minnesota, 358 U.S. 450 (1959).

${ }^{71}$ Northwest Airlines v. Minnesota, 322 U.S. 292, 302 (1944) (concurring opinion): McCarroll v. Dixie Greyhound Lines, 309 U.S. I76, I85, I88 (1940) (dissenting opinion).

${ }^{72}$ Northwestern States Portland Cement Co. v. Minnesota, 358 U.S. 450, 470, 477 (r959) (dissenting opinion). In a footnote, Mr. Justice Frankfurter called attention to the Australian resolution of the problem, which is a national arrangement whereby taxes are collected by the Commonwealth, and from these revenues, appropriate allocations are made annually to the states through the mechanism of a Prime Ministers' Conference. Id. at $476-77$ n. 4 .
} 
One writer, in discussing the tax situation in New Jersey above referred to, has specifically suggested the kind of an amendment which might be made to the Interstate Commerce Act: :33

No state shall, through taxation, expropriate such a share of the net income of a carrier earned within the state that, if a like share were expropriated by each of the other states in which the carrier operates, the result would be either to impair the carrier's credit or to weaken or incapacitate it as an instrumentality of interstate commerce.

Federal legislation of this sort would necessarily result in marked inroads on local governmental powers. Such action will hardly be palatable to those who believe in states' rights in this field and who resent the relentless intrusion of the federal government into local affairs. Such action would be even more unpalatable to those who view-and perhaps rightly-federal aid of any kind as the first step towards nationalization. If those fears are well grounded, and ultimate nationalization of the railroads were to take place, it would be followed by nationalization of all forms of transport, since the federal government would hardly countenance continuing subsidy of airways, highways, and waterways in competition with its own rail operations. Moreover, if the Government withdrew subsidies to those other forms of transportation, many of them would thereby be confronted with insurmountable financial problems, especially in a business recession, and they would likewise fall into government hands.

For numerous reasons, this paper has advocated action by local governments not only because the problem demands, and is capable of, solution at that level, but because it is, on the whole, desirable to forestall further incursions by the federal government into local affairs. A forthright and courageous approach to the problem is needed. Appealing reasons for avoidance of the issue are easily found. Commissioner Landis, of the New York Public Service Commission, in his supplementary concurring memorandum printed as a part of the report ${ }^{74}$ after noting state taxes paid to other states by certain New York railroads, says that the report should "condemn strongly the unwisdom" of any across-the-board tax reduction because the "disparate figures" of taxation in other states, which he notes New Jersey exacts "in a truly discriminatory manner, ... illustrate the inequities involved if New York should take unilateral action along the lines suggested."75 Except for New Jersey, could there be a more appropriate state than New York (which currently taxes railroads at three times the national average) to lead the way to equality and justice in taxation through unilateral action?

It is all too easy both for particular industries and geographic localities faced with difficult problems to thrust the solution on Congress, and evidence of this proclivity is forthcoming every day. Indeed, the recent report of the New York Public Service Commission, although recognizing certain areas in which the local

${ }^{7}$ Haskins, The Discriminatory Effect of Multiple State Taxation of Interstate Carriers, 5 J. Pub. L. $327,341-42$ (1956).

is Public Service CoMm'N, op. cit. supra note 12, at 47 .

${ }^{75} 7 d$. at 56 . 
governments must aict, expressly disclaims the power of the states to resolve the general passenger service problem, even within its own borders. "We are compelled," states the report, "to look to Washington for its regulation. We must also look to Washington for its salvation." ${ }^{\text {"76 }}$ And, in his concurring memorandum, Commissioner Landis states that "the problem of passenger deficits, even with respect to the New York railroads, is basically a national and not a state problem."77

A more encouragingly realistic, though still somewhat limited, approach to the problem caused by the onerous tax burden imposed upon railroads scrving New York State is contained in a special report to Governor Rockefeller, dated March 12, 1959.78 The report of a committee headed by Robert W. Purcell reached several basic conclusions from its study of the New York tax structure:

I. Serious discrepancies exist between communities within the state as regards railroad taxation.

2. Railroad taxation is inequitable and excessive.

3. Taxation of railroads has cost the state many millions of dollars in investments and payrolls and, unless corrected, will result in a further decline in business activity in the state in relation to that of other states.

In order to halt further deterioration of the railroads serving New York State and in order to grant a modest program of tax relief, the committee proposed the following program:

I. Immediate elimination of the special franchise tax on the intangible rights of the railroads.

2. A freeze at current levels of all other railroad real property and special franchise taxes.

3. Exemption from taxation of such improvements as grade crossing eliminations, protective devices at grade crossings, and other installations made primarily in the public interest, as well as elimination of taxation on the increased value created by other railroad reconstruction.

4. A change in the basic method of taxing railroads which would go into effect gradually over a four-year period. Taxes would be computed on a special formula which gives greater emphasis in the taxation system to the element of economic worth, while still retaining, but to a less important extent, the traditional concept of reproduction costs. Under this special formula, taxes would fluctuate from year to year, depending in part upon the earnings of the railroads averaged over the prior five years.

The report recognizes the extent of the New York tax burden, noting that even with the recommended changes, railroad taxes in New York would still be among the

${ }^{30}$ Id. at 27.

${ }^{7 \pi} I d$. at $6 \mathrm{x}$.

${ }^{38}$ Robert W. Purcell, Special Report to the Governor on Problems of the Railroad and Bus LiNES IN NEW YoRK STATE (1959). 
highest in the nation and twice as high per mile of road as in most of the midwestern states through which the main railroad systems run.

It must be emphasized that more is involved than the economic problems of the railroads, the inequalities and discrimination in favor of competitors, or the threat of nationalization. From the earliest days of the Republic, the structure of the government of the United States has presupposed a balance between national and local power. Historically, the strength of the federal and of the local governments has depended on mutual restraint and mutual support. In the context of the American constitutional system, as it has developed and now exists, the balance is not only one of power, but of jurisdiction. As men come to believe that local freedom and local rights are hindrances to efficiency or are incapable of accomplishing desired ends and objectives, they tend to turn to simple but autocratic remedies. In a free society, government must remain in touch with its citizens through local political organization, in order that an efficient central government be tempered by a regime of strong local governments.

In the course of a recent address, Dean Pound, of the Harvard Law School, has referred to "the enormous development of transportation and communication" which makes the area of the locality with separate interests more and more difficult to define, and he then went on to say: ${ }^{79}$

A federal government requires balance. It is organized on the idea of balance-balance of state and nation, balance of locality and state, balance of individual and society, balance of the general security and the individual life. Balance is by no means an obsolete idea of the eighteenth century. It is only by achieving and maintaining these balances that a single political organization can rule a whole continent except as an autocracy.

${ }^{78}$ Pound, Why Law Day?, Harv. Law School Bull. X, Dec. 1958, pp. 3, 7. 